\title{
Breakdown in Marriage A study of the social impact of the cases of marital maladjustment in the process of divorce (With special reference to Gwalior district)
}

\author{
Dr. Shraddha Sharma \\ Assistant Professor - Amity University, NOIDA
}

\begin{abstract}
Marriage has always been regarded as the most important institution in our society. It is a chord that binds two people (husband \& wife) and their families in such a way that though not bonded by blood or being strangers for ages they become closest of relatives. But after marriage there comes a new set of expectations, responsibilities and duties along with rights not only for the couples but also for the families involved \& here the problem begins. If the couples and their families are able to cope up with the new emerging set of life, the marriage turns into bliss but if they fail, it leads to marital maladjustment which ultimately leads the couple to the court for divorce.

The institution of divorce is still recognized as a social stigma in Indian society. It leads to a change in all the social relations, a man has been enjoying in his life. The family, friends, neigbours \& relatives who generally form the social circle of an individual mostly choose to back out or avoid when it comes to providing support in one way or the other to the couple under divorce process. The couple also avoids being part of the social gatherings for the fear of being queried by the people.

Therefore focusing on the majority of Hindus the present study has been undertaken by the scholar to explore deeply into the social impact of marital maladjustment.

The aim of this study is to find out the social impact of breakdown in marriage in newly married couples, which leads them to divorce, and on the basis of these findings of the study, to forward creative suggestions for the ramification of the problem.

Under this study for assessing the social impact of marital maladjustment in the process of divorce on the couples, the scholar has made use of indicators like change in social attitude, participation in parties/functions, social interaction, visits by people, social support etc.
\end{abstract}

\section{Sources \& Tools of Data Collection}

The Population of the study (or the source from which the primary data was collected) were the newly married couples (married some 6 years as lesser period back) who were registered for divorce in the family court \& VII A-D-J (district court) of Gwalior District under the Hindu Marriage Act 1955 from the period of August 2002 to December 2007.

In the present study the information was collected through an interview schedule.

\section{Sample Design}

In the present study the researcher made use of multi stage sampling method .A sample of 100 husbands \& 100 wives was selected from amongst the entire population of target couples, registered for divorce in the family court and VII A-D-J (district court) of Gwalior District under the Hindu Marriage Act 1955 from the period of August 2002 to December 2007 (which would amount to 200 respondents).

\section{Main findings of the study}

Change in the attitude of society (Family, Relatives, and Friends \& Neighbors)

Majority of husbands ( 88 percent) \& wives ( 80 percent) reported that there is no change in the attitude of family members after the issue.

Among those who reported that the attitude of family has changed after the issue, majority of husbands (50 percent) reported that the family does not involve them in the important decisions of the family while majority of wives informed that the attitude of family members has changed positively i.e. they shower extra love and care upon them in order to make them comfortable.

Majority of husbands(51 percent) \& wives( 62 percent) reported that the attitude of relatives have changed after the issue $\&$ followed by them were the husbands( 42 percent $) \&$ wives ( 36 percent) who reported that that their relatives don't know about the issue.. 
Among the husbands \& wives who reported that the attitude of relatives has changed after the issue, majority of husbands ( 82.35 percent) as well as wives (77.42 percent) reported that the relatives have lost respect for their families.

Majority of husbands (67 percent) \& wives (65 percent) reported that the attitude of friends has changed after the issue.

Among the husbands \& wives who reported change in the attitude of friends after the issue, majority of husbands (89.56 percent) \& wives ( 83.07 percent) have stated that their friends ignore or avoid them after the issue.

Majority of husbands (78 percent) as well as wives (76 percent) reported change in the attitude of neighbours after the issue.

Among the husbands \& wives who reported change in the attitude of neighbours after the issue, majority of husbands ( 69.23 percent) \& wives (67.1 percent) have stated that their neighbours have lost respect for their families after the issue. A few husbands (16.66 percent) \& wives ( 21.05 percent) also reported that their neighbours treat them differently i.e. as if they different from the normal people.

\section{Social Interaction}

Majority of husbands (68 percent) \& wives (62 percent) reported that they have need-based interaction with their family members i.e. they interact with them only when there is some need to talk to, after the issue.

Majority of husbands (43 percent) reported that they have need based interaction with their relatives \&followed by them were the husbands ( 42 percent) who stated that their relatives do not about the issue While majority of wives (37 percent) reported that they have formal interaction with the relatives \& followed by them were the wives ( 36 percent) who said that their relatives don't know about the issue.

Majority of husbands (49 percent) \& wives (38 percent) reported that they have formal interaction with their friends $\&$ followed by them were the husbands ( 28 percent) $\&$ wives ( 34 percent) who said that their friends don't know about the issue.

Majority of husbands (67 percent) \& wives (62 percent) reported that they have formal interaction with their neighbours after the issue.

\section{Social Participation (Participation in parties/ functions \& get together alone or along with family) after the issue}

Majority of husbands ( 74 percent) \& wives ( 80 percent) reported that they do participate in parties, functions \& get together alone or along with their families but very rarely.

\section{Visit by relatives, friends $\&$ neighbors after the issue}

Majority of husbands (42 percent) reported that their relatives don't know about the issue \& followed by them were the husbands ( 35 percent) who stated that the visits by relatives have become less frequent. While majority of wives ( 41 percent) reported that the visit by relatives have become less frequent, followed by wives(36 percent) who said that their relatives do not about the issue( see Table No. 6.10).

Majority of husbands (61 percent) \& majority of wives (59 percent) reported that the visits by friends have become less frequent after the issue.

Majority of husbands (72 percent) \& majority of wives (65 percent) reported that the visits by neighbours have become less frequent after the issue.

\section{Social support over the issue}

Majority of husbands ( 88 percent) \& wives (98 percent) responded positively about the support from family over the issue.

Among those couples who reported about the support of family over the issue majority of husbands (90.91percent) \& wives ( 93.88 percent) reported that they have all kind of support by the family i.e. financial, emotional, family members accompanying to court, lawyers etc.

Majority of husbands (42 percent) reported that their relatives don't know about the issue \& followed by them were the husbands ( 36 percent) who stated that their relatives do not have any support over the issue. While majority of wives (44 percent) reported that there is no support of relatives over the issue, followed by them were the wives ( 36 percent) who said that their relatives do not know about the issue.

Among those couples who reported about the support of relatives, majority of husbands (50 percent) \& wives (50 percent) stated that they have all kind of support by relatives over the issue.

Majority of husbands (48 percent) \& wives ( 45 percent) reported that their friends do not provide them any kind of support over the issue whereas followed by them were the husbands ( 28 percent) $\&$ wives ( 34 percent) who stated that either they don't have any friends or their friends don't know about the issue. 
Among those couples who stated that their friends do support them over the issue majority of husbands (45.83 percent) informed about all kind of support from their friends \& followed by them were the husbands(41.66 percent) who stated that their friends only provide them emotional support i.e. either sympathize them or encourage them to face the situation with patience $\&$ courage. While majority of wives ( 80.9 percent) reported that their friends only provide them emotional support.

Majority of husbands (62 percent) \& wives (61 percent) reported that they do not have any support by neighbours over the issue.

Among those who reported about the support of neighbours, majority of husbands ( 75.75 percent) \& wives (66.66 percent) stated that their neighbours only support them emotionally over the issue.

\section{Consequences experienced due to social stigma}

Majority of husbands (49 percent) reported that they have faced difficulty in finding a suitable match for siblings due to the issue \& followed by them were the husbands ( 41 percent) who reported that they are often pushed into unacceptable social situation i.e. they have to hide the truth on peoples' queries about the issue \& thus feel embarrassed. While majority of wives ( 42 percent) reported that they are often pushed into unacceptable social situation \& followed by them were the wives( 38 percent) who reported that have faced difficulty in finding a suitable match for the sibling.

\section{Conclusion \& Suggestions}

On the basis of her study the scholar has forwarded certain creative suggestions for dealing with the problem of marital maladjustment among newly married couples:

A paper on Family adjustment or marital adjustment should be introduced at graduation level in all education streams to prepare the young girls and boys for their duties \& responsibilities after marriage. Its syllabus should essentially focus on the importance of marriage \& various problems for example related to adjustment or behaviour, that has to be faced by the both the spouses living nuclear or along with family after marriage. The syllabus of the paper should also be renewed from time to time.

A system of compulsory Pre-marital counseling should be introduced in the Indian set up for the couples entering the marriage alliance and also for their parents. More and more human resource should be developed for meeting the requirement. It should also include a follow- up programme after every 6months until the period of 3 years after marriage of the couples

Frequent socialization of the girl/boy with elderly people in neighbourhood or community in the pre-marriage days can serve as an important tool in developing within them conformity towards various social institutions and cultural norms.

Parents of both husband \& wife should realize that after marriage the couples have their new roles and set of responsibilities \& so should not interfere much in their lives.

\section{References}

[1]. BERNARD, JESSIE, “The Distribution of Success in Marriage,” American Journal of Sociology, Vol. 39, No. 2, September 1933, pp. 194-203.

[2]. CHESSER, EUSTACE, The Sexual, Marital and Family Relationships of English Woman. Great Britain, Hutchinson's Medical Publications Ltd., 1956.

[3]. CHRISTENSEN, H.T., Marriage Analysis: Foundations for Successful Family Life, New York, Ronald Press Co., 1950

[4]. CORMACK, MARGARET, The Hindu Woman (Ist Indian Edition), Bombay, Asia Publishing House, 1961.

[5]. ELLIOTT, MABEL A. AND MERRILL, FRANCIS, E., Social Disorganization (3rd Edition), New York, Harper and Brothers Publishers, 1950.

[6]. KAPADIA, K.M., The Hindu Marriage and Divorce Bill, A Critical Study, Bombay Popular Book Depot, 1953.

[7]. Kapur, P (Smt); Marriage \& The Working Women in India, 1982.

[8]. KINSEY, ALFRED C. et al., Sexual Behaviour in the Human Male, Philadelphia, W.B. Saunders Company, 1948.

[9]. KUPPUSWAMY, B., Opinion Regarding Marriage and Divorce, Bombay, Asia Publishing House, 1957.

[10]. WILLIN, PAUL, "Marital Happiness of Parents and their Children's attitude to Marriage," American Sociological Review, February 1954, pp. 20-3.

[11]. WINCH, ROBERT F. AND McGINNIS, ROBERT (eds.), Marriage and the Family, New York, Henry Holy and Company, 1953. 